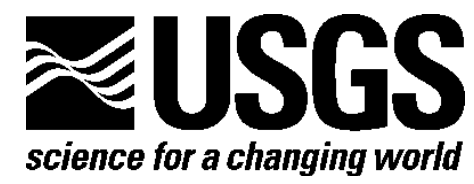

\title{
Digital Data from the Northeast Tusas Mountains Aeromagnetic Survey, Rio Arriba and Taos Counties, North-Central New Mexico
}

By B.J. Drenth, V.J.S. Grauch, and EDCON-PRJ, Inc.

Open-File Report 2011-1165 


\section{U.S. Department of the Interior \\ KEN SALAZAR, Secretary}

\section{U.S. Geological Survey \\ Marcia K. McNutt, Director}

U.S. Geological Survey, Reston, Virginia 2011

For product and ordering information:

World Wide Web: http://www.usgs.gov/pubprod

Telephone: 1-888-ASK-USGS

For more information on the USGS-the Federal source for science about the Earth,

its natural and living resources, natural hazards, and the environment:

World Wide Web: http://www.usgs.gov

Telephone: 1-888-ASK-USGS

Suggested citation:

Drenth, B.J., Grauch, V.J.S., and EDCON-PRJ, Inc., 2011, Digital data from the northeast Tusas Mountains aeromagnetic survey, north-central New Mexico: U.S. Geological Survey Open-File Report 2011-1165, 5 p.

Any use of trade, product, or firm names is for descriptive purposes only and does not imply endorsement by the U.S. Government.

Although this report is in the public domain, permission must be secured from the individual copyright owners to reproduce any copyrighted material contained within this report. 


\section{Digital Data from the Northeast Tusas Mountains Aeromagnetic Survey, Rio Arriba and Taos Counties, North-Central New Mexico}

By B.J. Drenth ${ }^{1}$, V.J.S. Grauch ${ }^{1}$, and EDCON-PRJ, Inc. ${ }^{2}$

${ }^{1}$ U.S. Geological Survey, Denver, CO
${ }^{2} 171$ S. Van Gordon St., Denver, CO

Abstract

This report contains digital data, image files, and text files describing data formats and survey procedures for a high-resolution aeromagnetic survey in the northeast Tusas Mountains region of northcentral New Mexico. The survey covers a large portion of the Tres Piedras Ranger District of the Carson National Forest and adjacent areas, northwest of the town of Tres Piedras.

Several related and derivative products from these data are also presented as grids and images, including radar-altimeter heights, analytically draped aeromagnetic data, the elevation surface used for draping, and reduced-to-pole aeromagnetic data. Images are presented in various formats and are intended to be used as input to geographic information systems, standard graphics software, or mapplotting packages.

\section{Introduction}

This report describes data collected from a high-resolution aeromagnetic survey flown over the northeast Tusas Mountains region of north-central New Mexico (fig. 1). The survey covers a large portion of the Tres Piedras Ranger District of the Carson National Forest and adjacent areas, northwest of the town of Tres Piedras. The survey was flown in October 2010 by EDCON-PRJ, Inc. and El Aero Services, Inc. on contract to the U.S. Geological Survey (USGS). Scientific objectives for the northeast Tusas Mountains survey are to investigate the geology of volcanic rocks and subsurface structural framework that may influence groundwater hydrology and seismic hazards. Funding was provided by the Crustal Geophysics and Geochemistry Science Center of the USGS. The eastern portion of this survey area connects with high-resolution aeromagnetic surveys flown previously in the southern and central San Luis Basin (Bankey and others, 2004; Bankey and others, 2005; Bankey and others, 2006; Bankey and others, 2007; Drenth and others, 2009). The surveys are part of an ongoing USGS project called "Geologic Framework of Rio Grande Basins," with an overall goal to understand the subsurface geologic framework of the San Luis Basin in order to improve input to regional groundwater models. 


\section{Organization of Data}

The "00README.txt" file provides summaries of the file contents. The folders are organized as follows: files pertaining to this report are contained in the "report" folder; files pertaining to the gridded data are contained in the "grids" folder; files pertaining to the flight-line data are contained in the "linedata" folder; and files pertaining to color shaded-relief images are contained in the "images" folder. In the data folders, ASCII files with the extension ".txt" describe the format and contents of the data files. Please read the ".txt" files before using the data files.

\section{Description of Data}

Aeromagnetic data are collected using airborne geophysical sensors that measure subtle variations in the Earth's magnetic field. Aeromagnetic surveys are designed to map the variations caused by the irregular distribution of naturally occurring magnetic minerals associated with geologic features. High-resolution surveys such as these are flown closer to the ground and with narrower line spacing than conventional aeromagnetic survey to better detect weakly magnetic rocks and sediments, as well as anomalies of smaller areal extent. Mapping the three-dimensional underground distribution of these features helps scientists understand the geologic controls on regional groundwater systems.

The aeromagnetic survey was flown by a helicopter equipped with a towed bird (containing a cesium-vapor magnetometer and GPS system) flying along traverse lines spaced $200 \mathrm{~m}$ (about $656 \mathrm{ft}$ ) apart and oriented east-west. Over most of the survey area, the pilot followed a pre-planned flight surface that was generally $100 \mathrm{~m}(328 \mathrm{ft})$ above ground. The aircraft smoothly increased in flight height, subject to safety precautions, to equalize rates of climb and descent over high topography. Orthogonal tie lines were flown north-south at a $1,500 \mathrm{~m}(4,920 \mathrm{ft})$ spacing at the same elevation as the traverse lines. Total flight-line coverage was 3531.9 line-kilometers (2194.6 line-mi). The orientation of traverse lines was chosen to be oblique to the predominant geologic strike of the area.

\section{Data Processing}

Contractor-provided details of the flight specifications, survey procedures, and data processing are included in Appendix 1.

Apparent residual lag problems existed in the initial magnetic processing, as manifested by lineto-line shifts of linear anomalies. An additional lag shift of 5 fiducials ( $\sim 15 \mathrm{~m}$ or $\sim 49 \mathrm{ft})$ was found empirically to provide an optimum solution. The line data provided here include two versions of the final magnetic data, one without the additional lag correction, and one with the additional lag correction applied.

The magnetic and radar data were interpolated onto a grid at 50-m intervals. The map projection used is Universal Transverse Mercator (UTM), zone 13 (central meridian of $105^{\circ} \mathrm{W}$ longitude, a false easting of 500,000 m, a false northing of $0 \mathrm{~m}$ ). The UTM projection was applied using both the North American Datum of 1927 (NAD27) and WGS84 datums. The gridded altitude data are included in the 'grids' directory and contain the phrase 'radar' in the file name.

The aeromagnetic data were not acquired at a terrain clearance of $100 \mathrm{~m}$ everywhere, due to difficulties flying in rough terrain. To enhance details and provide better consistency for interpretation, the final magnetic grid was continued to a simulated flight surface of $100 \mathrm{~m}$ above the ground, using the "chessboard" draping method of Cordell (1985), as implemented by Geosoft Oasis montaj ${ }^{\mathrm{TM}}$. In this continuation method, data are extrapolated from a series of parallel continuation surfaces that have each been computed using standard Fast Fourier Transform (FFT) techniques. The grid of radar-altimeter 
values was used to determine the distances to upward- or downward-continue the data to a common terrain clearance of $100 \mathrm{~m}$. A low-pass filter was applied during downward continuation based on a cosine-squared roll-off function that increases the wavelength cutoff with greater continuation distance. Through trial and error we used a wavelength cutoff that is inversely proportional to 1.5 times the continuation distance.

Supplementary filtering was required to minimize noise that was enhanced during continuation. First, additional decorrugation filtering was applied, following the method of Urquhart (1988), modified for use with a Blackman window (Oppenheim and Schafer, 1975; Sweeney and others, 2002; Phillips, 2007). A Blackman window with a filter of 11 grid points was convolved with the magnetic data along the grid rows (the direction of the traverse lines), resulting in both a high-pass grid and a low-pass grid. The same Blackman window was then convolved with the data along the columns of the low-pass grid (the direction of the tie lines) to remove flight-line "corrugations". The high-pass grid was added to this filtered grid to retain the short-wavelength information in the direction of the flight lines. Because some anomalies related to geology are inevitably removed by decorrugation, both decorrugated (phrase 'contdcor') and non-decorrugated (phrase 'cont') magnetic grids are included here.

A standard reduction-to-pole operator (Baranov and Naudy, 1964; Blakely, 1995) was applied to the continued and decorrugated magnetic data. This operation, resulting in reduced-to-pole (RTP) data, corrects for shifts of the main anomaly from the center of the magnetic source that occur at most latitudes owing to the oblique orientation of the measured magnetic field with respect to the Earth's surface (the field is vertical only at the magnetic poles). From geomagnetic field models, the declination and inclination of the Earth's field are $10^{\circ}$ and $64^{\circ}$, respectively. To apply the reduced-to-pole transformation, one must assume that the total magnetizations of most rocks in the study area align parallel or anti-parallel to the Earth's main field.

More complete descriptions of the data can be found in the text files in each folder, and in the contractor's report (Appendix 1). 


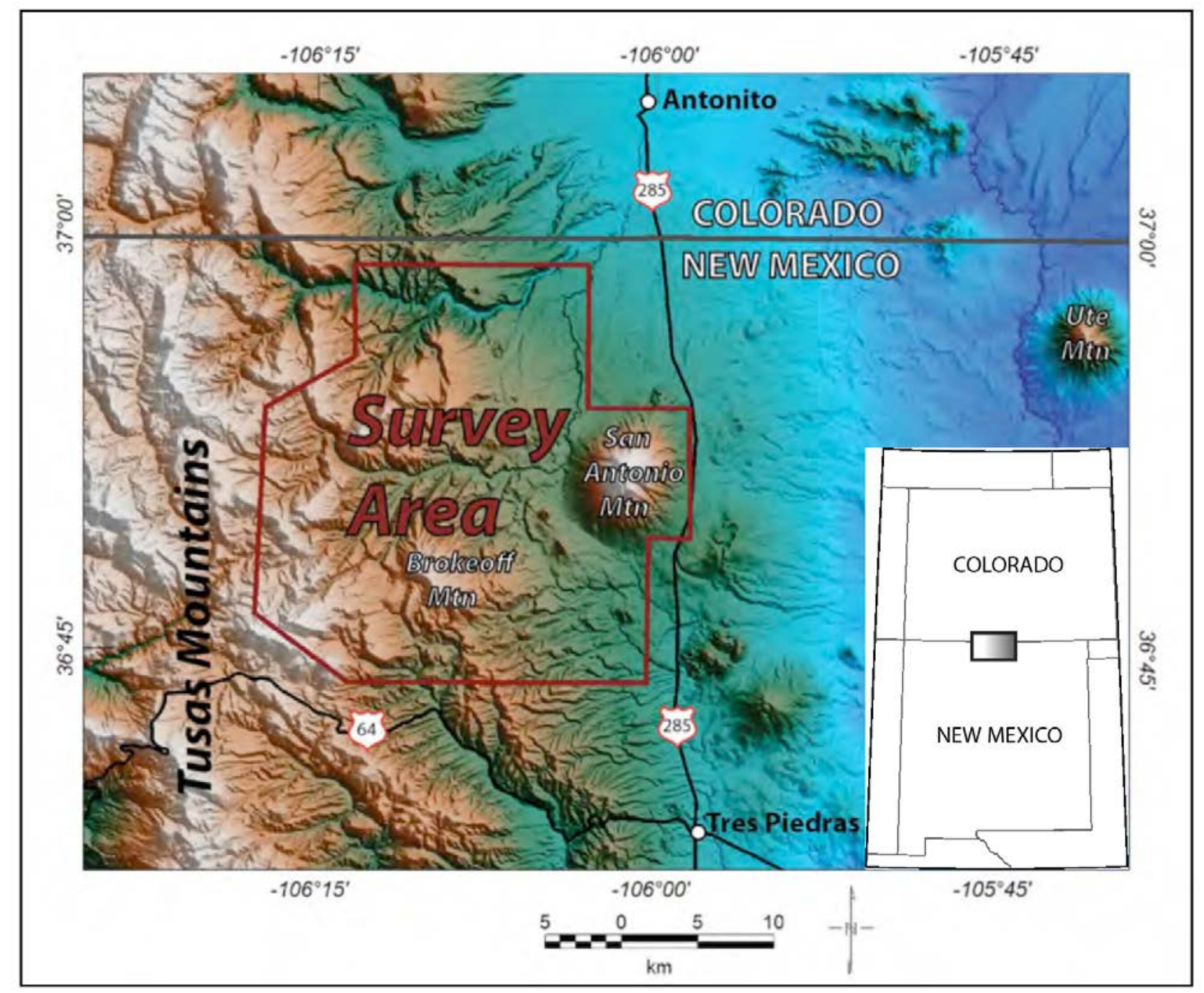

Figure 1. Location of the northeast Tusas Mountains survey. 


\section{References Cited}

Bankey, V., Grauch, V.J., and Fugro Airborne Surveys Corporation, 2004, Digital aeromagnetic data and derivative products from a helicopter survey over the Town of Taos and surrounding areas, Taos County, New Mexico: U.S. Geological Survey Open-File Report 2004-1229.

Bankey, V., Grauch, V.J., Webbers, A., and PRJ, Inc., 2005, Digital data and derivative products from a high-resolution aeromagnetic survey of the central San Luis basin, covering parts of Alamosa, Conejos, Costilla, and Rio Grande Counties, Colorado, and Taos County, New Mexico: U.S. Geological Survey Open-File Report 2005-1200.

Bankey, V., Grauch, V.J., Drenth, B.J., and Geophex, Ltd., 2006, Digital data from the Questa-San Luis and Santa Fe East helicopter magnetic surveys in Santa Fe and Taos Counties, New Mexico, and Costilla County, Colorado: U.S. Geological Survey Open-File Report 2006-1170.

Bankey, V., Grauch, V.J., Drenth, B.J., and EDCON-PRJ Inc., 2007, Digital data from the Taos West aeromagnetic survey in Taos County, New Mexico: U.S. Geological Survey Open-File Report 2007-1248.

Baranov, V. and Naudy, H., 1964, Numerical calculation of the formula of reduction to the magnetic pole: Geophysics, v. 29, p. 67-79.

Blakely, R.J., 1995, Potential Theory in Gravity and Magnetic Applications: New York, Cambridge University Press, $441 \mathrm{p}$.

Cordell, L., 1985, Techniques, applications, and problems of analytical continuation of New Mexico aeromagnetic data between arbitrary surfaces of very high relief: Proceedings of the International Meeting on Potential Fields in Rugged Topography, Institute of Geophysics, University of Lausanne, Switzerland, Bulletin no. 7, p. 96-101.

Drenth, B.J., Grauch, V.J., Bankey, V., and New Sense Geophysics, Ltd., 2009, Digital Data from the Great Sand Dunes and Poncha Springs Aeromagnetic Surveys, South-Central Colorado: U.S. Geological Survey Open-File Report 2009-1089.

Oppenheim, A.V. and Schafer, R.W., 1975, Digital Signal Processing (1st ed.): Englewood Cliffs, NJ, Prentice-Hall, Inc., 585 p.

Phillips, J.D., 2007, Geosoft eXecutables (GX's) developed by the U.S. Geological Survey, version 2.0, with notes on GX development from Fortran code: U.S. Geological Survey Open-File Report $2007-1355,111 \mathrm{p}$.

Sweeney, R.E., Grauch, V.J., and Phillips, J.D., 2002, Merged digital aeromagnetic data for the Albuquerque and southern Espanola Basins, New Mexico: U.S. Geological Survey Open-File Report 02-205, $15 \mathrm{p}$.

Urquhart, T., 1988, Decorrugation of enhanced magnetic field maps-Expanded Abstracts and Biographies: Society of Exploration Geophysicists, 58th Annual Meeting, Anaheim, CA, v. 7, p. 371-372. 